\title{
An open-label study to evaluate a single-dose of cinacalcet in pediatric dialysis subjects
}

\author{
Desmond Padhi • Craig B. Langman • \\ Sahar Fathallah-Shaykh • Bradley A. Warady • \\ Isidro B. Salusky • Edward Lee • Christine Wang • \\ Edward Posvar
}

Received: 20 July 2011 /Revised: 29 March 2012 / Accepted: 30 March 2012 / Published online: 26 May 2012

(C) The Author(s) 2012. This article is published with open access at Springerlink.com

\begin{abstract}
Background There is limited knowledge of the effectiveness and safety profile of cinacalcet in pediatric patients with secondary hyperparathyroidism (sHPT) treated with dialysis.

Methods This was an open-label, single-dose study conducted on 12 pediatric subjects with chronic kidney disease treated with dialysis. Subjects were stratified by four age cohorts and given a single $15-\mathrm{mg}$ oral dose of cinacalcet. Multiple blood samples were collected up to $72 \mathrm{~h}$ post-dose for the assessment
\end{abstract}

D. Padhi $(\bowtie) \cdot$ C. Wang $\cdot$ E. Posvar

Early Development, Amgen Inc.,

One Amgen Center Dr., M/S 38-3-A,

Thousand Oaks, CA 91320, USA

e-mail: dpadhi@amgen.com

\section{B. Langman}

Feinberg School of Medicine, Children's Memorial Hospital,

Northwestern University,

Chicago, IL, USA

S. Fathallah-Shaykh

Division of Pediatric Nephrology, University of Alabama

at Birmingham,

Birmingham, AL, USA

B. A. Warady

Children's Mercy Hospitals and Clinics, University

of Missouri-Kansas City School of Medicine,

Kansas City, MO, USA

I. B. Salusky

Division of Pediatric Nephrology, Department of Pediatrics,

David Geffen School of Medicine at UCLA,

Los Angeles, CA, USA

E. Lee

Metabolic Disorders, Amgen Inc.,

Thousand Oaks, CA, USA of serum calcium $(\mathrm{Ca})$, serum intact parathyroid hormone (iPTH), and plasma cinacalcet concentrations.

Results Overall, cinacalcet was well tolerated with no serious adverse events. Mean (standard deviation) percentage change in serum $\mathrm{Ca}$ over the first $12 \mathrm{~h}$ post-dose was $-2.93 \%(5.70 \%)$ with a nadir of $-4.34 \%(6.04 \%)$ at $8 \mathrm{~h}$; Ca values returned to baseline by $48 \mathrm{~h}$ post-dose. Mean percentage change in iPTH over the first $12 \mathrm{~h}$ post-dose was $57.94 \%(71.82 \%)$ with a nadir of $-35.65 \%(55.82 \%)$ at $2 \mathrm{~h}$. There was an inverse relationship between peak serum Ca concentration and body surface area (BSA) $\left(r^{2}=0.41\right)$, although no relationship was found between area under the curve and age or BSA.

Conclusions These data support future analysis to determine the therapeutic starting dose of cinacalcet for pediatric patients with sHPT on dialysis.

Keywords Hyperparathyroidism · CKD-MBD .

Hemodialysis $\cdot$ End-stage renal disease $\cdot$ Pharmacokinetics . Pharmacodynamics $\cdot$ Secondary

\section{Introduction}

Pediatric and adult patients with chronic kidney disease (CKD) are subject to a unique constellation of signs and symptoms that affect bone and mineral metabolism, termed collectively, CKD-mineral and bone disorders (CKD-MBD). Part of the biochemical picture in CKD-MBD includes elevated blood levels of fibroblast growth factor 23 (FGF23) and reduced blood levels of calcitriol. Markedly high levels of FGF23 in combination with parameters of abnormal mineral metabolism are associated with progressive increases in serum intact parathyroid hormone (PTH), referred to as secondary hyperparathyroidism (sHPT). 
The hyperphosphatemia and hypocalcemia seen in CKDMBD worsens SHPT, a disease associated with bone disease as well as systemic cardiovascular and cutaneous toxicities [1]. Although therapies for sHPT include lowering serum phosphorus $(\mathrm{P})$ through dietary restrictions and the use of phosphate binders, supplementation of calcium $(\mathrm{Ca})$, vitamin D analogs, and parathyroidectomy [2], these options have significant limitations associated to dietary restrictions, medication non-adherence, as well as adverse reactions. In patients with end-stage renal disease (ESRD), vitamin D sterols are effective in the short term in lowering the serum concentration of PTH through both direct and indirect mechanisms [3, 4]. However, the efficacy of vitamin D sterols in suppressing iPTH may be reduced due to their potential to raise serum $\mathrm{Ca}$ and $\mathrm{P}$ levels.

The calcimimetic Sensipar ${ }^{\circledR} /$ Mimpara ${ }^{\circledR}$ (cinacalcet; Amgen, Thousand Oaks, CA) is an addition to existing dialysis therapies, designed to treat sHPT [5-8]. Cinacalcet belongs to a family of small organic allosteric activators of the G-protein-coupled calcium sensing receptor (CaSR) in the parathyroid glands and other tissues [9]. It increases the sensitivity of extracellular CaSR to extracellular $\mathrm{Ca}$. Activation of CaSR decreases both the synthesis and secretion of PTH [10] and subsequently decreases serum $\mathrm{Ca}$ and $\mathrm{P}$, as well as the $\mathrm{Ca}$ $\times \mathrm{P}$ product in adult dialysis patients. In such patients with sHPT on hemodialysis, cinacalcet has been shown to be effective in lowering PTH levels to clinically acceptable levels that satisfy biochemical target ranges defined by the Kidney Disease Outcomes Quality Initiative (K-DOQI ${ }^{\mathrm{TM}}$ for disease management $[5,7,8,11-13]$. Cinacalcet doses are adjusted based on response to PTH levels.

Approximately $80 \%$ of pediatric patients with CKD and on dialysis are treated for renal osteodystrophy. There is little evidence that parathyroid gland function differs in children and adolescents with ESRD compared to adults [14]. Thus, there is reason to believe that pediatric dialysis patients with sHPT will also respond to treatment with cinacalcet. To date, there are no published randomized controlled studies evaluating the safety and efficacy of cinacalcet in the pediatric dialysis population. However, several retrospective observational studies have demonstrated that PTH levels decrease following the initiation of cinacalcet treatment, including that of Silverstein et al. [15] who found decreased PTH levels within the first month of initiating cinacalcet treatment, with no change in $\mathrm{Ca}$, $\mathrm{P}$, or $\mathrm{Ca} \times \mathrm{P}$ after 3 months in nine pediatric dialysis patients, while Muscheites et al. [16] reported statistically significant and clinically relevant decreases for $\mathrm{PTH}, \mathrm{Ca}, \mathrm{P}$, and $\mathrm{Ca} \times \mathrm{P}$ within a 4-week treatment period. Although these findings are consistent with the literature on cinacalcet in the adult populations [17], both studies were based on adult dosing guidelines and illustrate the need to further investigate cinacalcet use prospectively in the pediatric dialysis population.
Limited therapeutic options highlight an unmet need for a more effective therapy for SHPT in pediatric patients on dialysis. Thus, the study reported here was designed to evaluate the safety, tolerability, pharmacokinetics, and pharmacodynamics of a $15-\mathrm{mg}$ dose of cinacalcet in pediatric subjects with SHPT treated with hemodialysis.

\section{Methods}

This was a single-dose, open-label study to evaluate the safety, tolerability, pharmacokinetics, and pharmacodynamics of cinacalcet in pediatric subjects with CKD on dialysis. The ethics committees of each study center reviewed and approved the study protocol and the consent forms prior to the investigators enrolling subjects. Twelve subjects were enrolled, and all subjects continued their regular therapy for management of sHPT (e.g., phosphate binder, vitamin $\mathrm{D}$ sterol). Oral or intravenous Ca therapy and alteration of the dialysate calcium concentration was allowed for serum $\mathrm{Ca}<1.87 \mathrm{mmol} / \mathrm{L}(7.5 \mathrm{mg} / \mathrm{dL})$ or signs or symptoms of hypocalcemia subsequent to the study drug administration.

Seven girls and five boys aged 6-17 years on dialysis for at least 1 month at the time of screening were enrolled in the study. Written informed consent was obtained from the parent or guardian for all subjects; additionally, written assent was obtained from subjects $\geq 12$ years of age. Subjects were eligible to participate if they had serum $\mathrm{Ca}$ level of $\geq 8.4 \mathrm{mg} / \mathrm{dL}$ at the time of the baseline visit and had not received any cinacalcet therapy for at least 2 weeks before Day 1 dosing.

To ensure subjects were enrolled across the entire age range of 6-17 years, three subjects were required to be enrolled into each of the following age-cohorts: $6-8,9-11,12-14$, and 1517 years. After a minimum 8 -h fast, each subject received a single oral $15-\mathrm{mg}$ dose of cinacalcet ( $1 / 2$ of a $30-\mathrm{mg}$ tablet, weighed with a Mettler balance) with $90 \mathrm{~mL}$ (3 oz) of water. Subjects continued to fast for $4 \mathrm{~h}$ after treatment administration, and they were followed for $72 \mathrm{~h}$ after dosing.

\section{Rationale for dosage selection}

In vitro and in vivo studies have demonstrated that cinacalcet is extensively metabolized by multiple cytochrome P450 (CYP) enzymes, including CYP3A4, CYP2D6, and CYP1A2 [18]. The capacity to metabolize drugs in children varies throughout development of CYP enzymes and is completed by approximately 6 years of age. Therefore, the difference in pharmacokinetic properties of cinacalcet for adults and pediatric patients older than 6 years is likely to be due to differences in body surface area (BSA). Based on BSA, a 6-year-old child should receive approximately $50 \%$ of an adult dose. The 
recommended starting dose for cinacalcet in adults is $30 \mathrm{mg}$; therefore, a dose of $15 \mathrm{mg}$ was selected for this study.

\section{Sample collection}

Blood samples for safety assessments were collected at screening, baseline, and on study Day 4. Blood samples for pharmacokinetic analysis were collected at predose and at 0.5 , $1,2,3,4,5,6,8,12,24,48$, and $72 \mathrm{~h}$ post-dose, and those for pharmacodynamic $(\mathrm{Ca}$ and $\mathrm{iPTH})$ analysis were obtained at predose and at $2,4,8,12,24,48$, and $72 \mathrm{~h}$ post-dose.

Planned statistical analysis

All subjects who received cinacalcet were included in the safety, pharmacokinetics, and pharmacodynamics analyses. Since this was a descriptive study, the sample size of three subjects per age-cohort was based on practical considerations; no formal analyses for between-cohort comparisons were conducted.

The safety profile assessment was based on adverse events, vital signs, clinical laboratory measurements, electrocardiogram, and physical examinations. An adverse event was defined as an undesirable medical sign or symptom or worsening of a pre-existing medical condition present at baseline that occurred after initiation of the investigational product. A serious adverse event included any event deemed fatal or life threatening, an event that required or prolonged in-patient hospitalization, or a persistent, significant disability or incapacity, congenital anomaly, or birth defect, as well as any event that may have resulted in urgent investigation.

Plasma cinacalcet concentration-time data were analyzed by non-compartmental methods using WinNonlin Enterprise (ver. 5.1.1; Pharsight Corp, Mountain View, CA). The serum peak concentration $\left(\mathrm{C}_{\max }\right)$ after dosing was identified by inspection of the data, and the corresponding time to reach $\mathrm{C}_{\max }\left(\mathrm{t}_{\max }\right)$ was recorded. Plasma cinacalcet concentration versus time was plotted on a semi-log-scale, and the data points that described the terminal log-linear segment of the elimination phase were identified. Whenever possible, a linear regression of the log-transformed terminal data points versus time was used to estimate the terminal rate constant $\beta$. The terminal half-life, $\mathrm{t}_{1 / \mathrm{s} \beta}$ was calculated as $0.693 / \beta$. The area under the concentration-time curve from zero to the last measurable concentration $\left(\mathrm{AUC}_{0-\mathrm{t}}\right)$ was calculated by the linear trapezoidal method. The AUC from the time of the last measurable concentration to infinity $\left(\mathrm{AUC}_{\mathrm{t} \text {-inf }}\right)$ was calculated by dividing the predicted concentration at the time of the last measurable concentration by $\beta$. The AUC from time zero to infinity, $\mathrm{AUC}_{\mathrm{o}-\mathrm{inf}}$, was calculated by the summation of $\mathrm{AUC}_{0-\mathrm{t}}$ and $\mathrm{AUC}_{\mathrm{t} \text {-inf. }} \mathrm{AUC}_{0 \text {-inf }}$ was not reported when $\mathrm{AUC}_{\mathrm{t} \text {-inf }}$ exceeded $20 \%$ of the total AUC. The apparent oral clearance $(\mathrm{CL} / \mathrm{F})$ was calculated as dose/ $\mathrm{AUC}_{0 \text {-inf. }}$

\section{Results}

Study subjects

Table 1 shows the baseline demographics of the 12 pediatric subjects with mean (SD) age of 11.3 (3.7) years receiving chronic hemodialysis or peritoneal dialysis that were enrolled in this single dose study. All subjects were included in all analysis sets.

Safety

Hypocalcemia $(\mathrm{Ca}<2.23 \mathrm{mmol} / \mathrm{L})$, a documented effect of cinacalcet in studies with adults, was reported in $50 \%(n=6)$ of subjects, with a range of $2.00-2.22 \mathrm{mmol} / \mathrm{L}$. Other reported $(n=2,17 \%)$ adverse events were mild to moderate in severity and assessed by the investigators to be unrelated to the study drug. Bacteremia and pyrexia (with normal $\mathrm{Ca}$ levels) were reported for one subject (age 11 years) 48 $\mathrm{h}$ post-dose. One subject (age 15 years) with a 6-month history of ESRD had an adverse event of QT interval prolongation within $72 \mathrm{~h}$ post-dose, which the investigator related to prior trauma. Subsequent electrocardiograms performed 2 and 6 weeks after the date of onset showed a prolonged QTc interval and non-specific ST segment changes. After the 3-month follow-up visit the subject was referred to a cardiologist who documented a normal QTc during assessment. Based on the cardiologist's report and the subject's negative family history for prolonged QT interval prolongation, the investigator considered the adverse event to be unrelated to the investigational product. Neither of these two subjects withdrew from the study due to the adverse event, and they reported no serious adverse events.

Of the 12 subjects, six had decreases in serum Ca below the lower limit of normal without any associated symptoms. The low $\mathrm{Ca}$ values for these subjects ranged from 2.00 to $2.20 \mathrm{mmol} / \mathrm{L}$ up to $12 \mathrm{~h}$ post-dose. No clinically significant trends were observed for the other serum chemistry, hematology, or urinalysis laboratory assessments.

Table 1 Baseline demographics

\begin{tabular}{ll}
\hline Patient baseline demographics & $15 \mathrm{mg}$ cinacalcet $(n=12)$ \\
\hline Female, $n(\%)$ & $7(58)$ \\
Hispanic or Latino, $n(\%)$ & $6(50)$ \\
Black or African American, n (\%) & $3(25)$ \\
White or Caucasian, $n(\%)$ & $3(25)$ \\
Age (years), mean (SD) & $11.33(3.68)$ \\
Height $(\mathrm{cm})$, mean (SD) & $136.13(20.53)$ \\
Weight $(\mathrm{kg})$, mean (SD) & $38.38(15.67)$ \\
BMI $\left(\mathrm{kg} / \mathrm{m}^{2}\right)$, mean (SD) & $19.85(3.53)$ \\
\hline
\end{tabular}

BMI, Body mass index; SD, standard deviation 


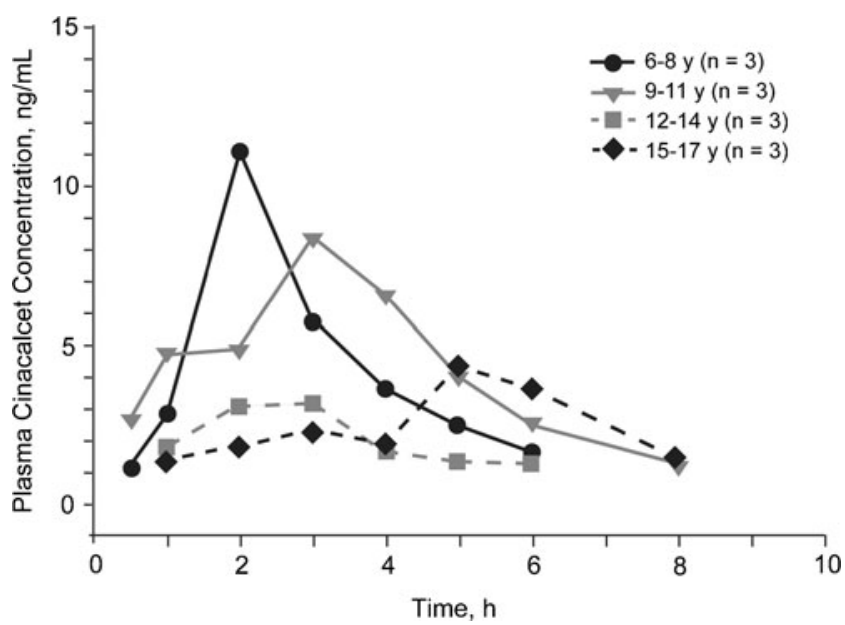

Fig. 1 Mean plasma cinacalcet concentration-time profiles following oral administration of 15 -mg cinacalcet

\section{Pharmacokinetics}

Mean plasma cinacalcet concentration-time profiles by agecohort are presented in Fig. 1. For the four age cohorts $(n=3$ in each), namely, 6-8 years, 9-11 years, 12-14 years, and 1517 years, the values for the pharmacokinetic parameters were: $\mathrm{AUC}_{0-\mathrm{t}}[\mathrm{h} \mathrm{ng} / \mathrm{mL}$; mean (SD)], 29.5 (15.6), 35.9 (35.8), 11.3 (4.4), and 17.5 (5.9), respectively; $\mathrm{C}_{\max }[\mathrm{mg} / \mathrm{mL}$; mean (SD)], 11.0 (3.2), 9.19 (7.28), 3.87 (1.82), and 5.01 (2.15),
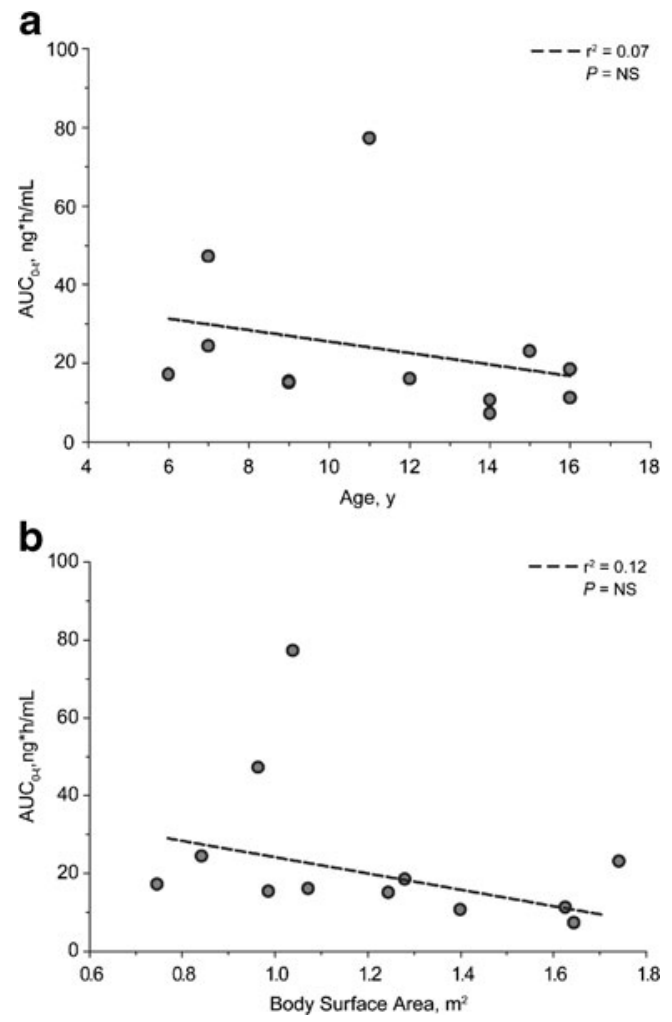

Fig. 2 a Area under the time-concentration curve from zero to the last measurable concentration $\left(A U C_{0-t}\right)$ by age for individual subjects. b $\mathrm{AUC}_{0-\mathrm{t}}$ by body surface area (BSA) for all subjects. NS Not significant
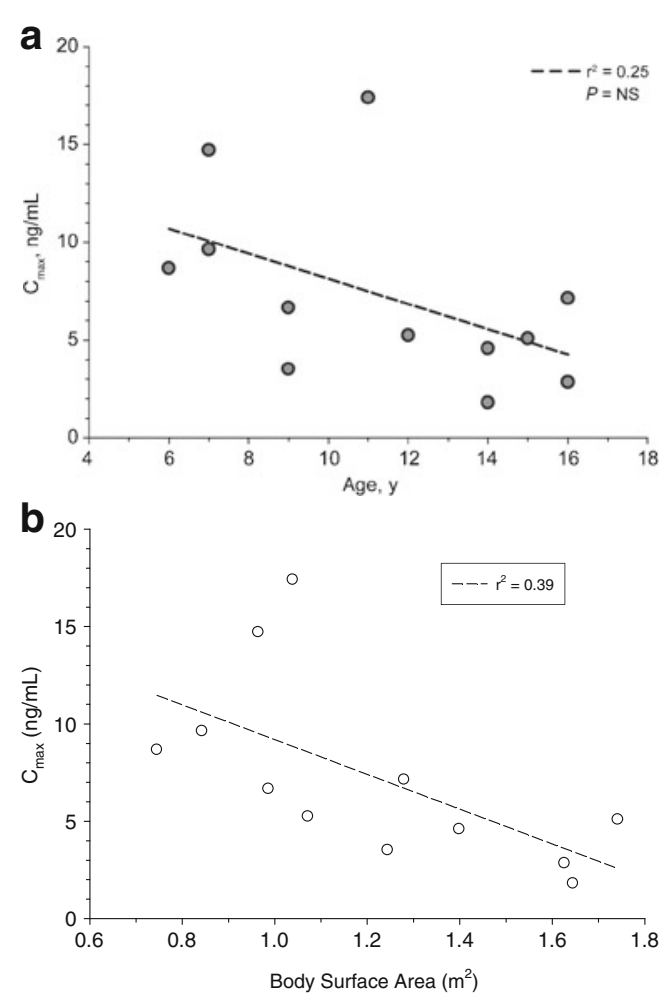

Fig. 3 a Serum peak cinacelcet concentration $\left(C_{\max }\right)$ by age for individual subjects. $\mathbf{b} \mathrm{C}_{\max }$ by BSA for individual subjects. NS Not significant

respectively; $\mathrm{t}_{\max }$ [h; median (min-max)], 2.0 (2.0-2.0), 3.0 (2.0-4.0), 3.0 (1.0-3.0), and 3.0 (2.0-5.0), respectively. Age and BSA versus $\mathrm{AUC}_{0-\mathrm{t}}$, and age and BSA versus $\mathrm{C}_{\max }$ are presented graphically in Figs. 2a, b and 3a, b, respectively.

Mean exposure $\left(\mathrm{AUC}_{0-\mathrm{t}}\right.$ and $\left.\mathrm{C}_{\max }\right)$ in the four agecohorts did not consistently increase with decreasing age.

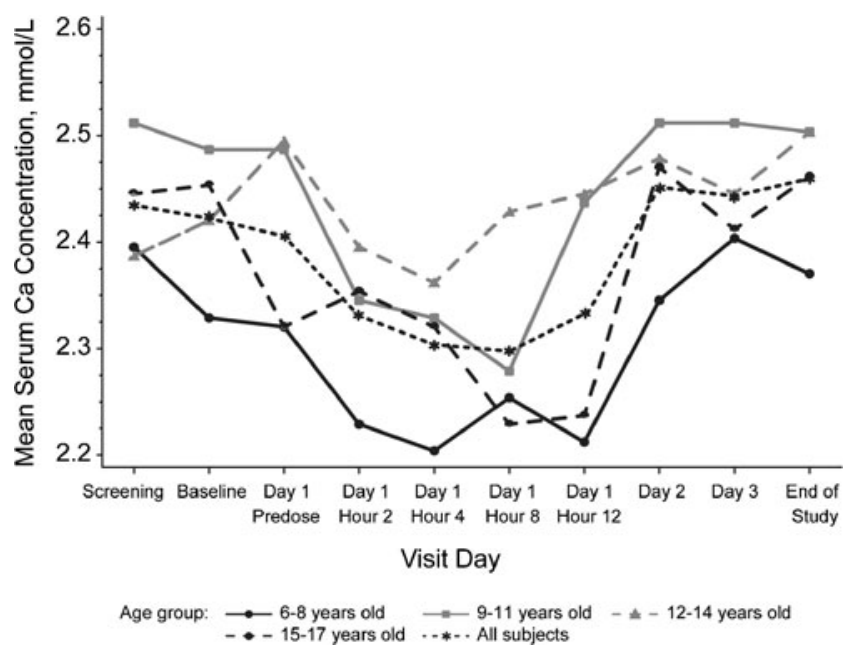

Fig. 4 Mean serum calcium $(\mathrm{Ca})$ concentrations by time for each age-cohort. For all subjects, the mean \pm standard deviation maximum decrease was $4.3 \pm 6.0 \% 8 \mathrm{~h}$ post-dose; Ca returned to the baseline level by Day 2 . The overall patterns of change from baseline were similar for all age-cohorts 
Table 2 Mean changes from baseline over time in serum calcium level for each age-cohort
Data are presented as the mean, with the standard deviation given in parenthesis

\begin{tabular}{|c|c|c|c|c|c|}
\hline \multirow[t]{2}{*}{ Time } & \multicolumn{4}{|l|}{ Age-cohort } & \multirow{2}{*}{$\begin{array}{l}\text { All subjects } \\
(n=12)\end{array}$} \\
\hline & $\begin{array}{l}6-8 \text { years } \\
(n=3)\end{array}$ & $\begin{array}{l}9-11 \text { years } \\
(n=3)\end{array}$ & $\begin{array}{l}12-14 \text { years } \\
(n=3)\end{array}$ & $\begin{array}{l}15-17 \text { years } \\
(n=3)\end{array}$ & \\
\hline \multicolumn{6}{|l|}{ Day 1 , hour 2} \\
\hline Absolute (mmol/L) & $-0.09(0.03)$ & $-0.14(0.13)$ & $-0.10(0.20)$ & $0.03(0.12)$ & $-0.07(0.13)$ \\
\hline Percentage & $-3.99(1.47)$ & $-5.51(4.63)$ & $-3.81(7.58)$ & $1.80(5.76)$ & $-2.88(5.40)$ \\
\hline \multicolumn{6}{|l|}{ Day 1, hour 4} \\
\hline Absolute (mmol/L) & $-0.12(0.07)$ & $-0.16(0.16)$ & $-0.13(0.20)$ & $0.00(0.26)$ & $-0.10(0.17)$ \\
\hline Percentage & $-5.13(3.43)$ & $-6.13(6.08)$ & $-5.18(7.71)$ & 0.78 (11.99) & $-3.92(7.35)$ \\
\hline \multicolumn{6}{|l|}{ Day 1 , hour 8} \\
\hline Absolute (mmol/L) & $-0.07(0.10)$ & $-0.21(0.12)$ & $-0.07(0.25)$ & $-0.09(0.12)$ & $-0.11(0.15)$ \\
\hline Percentage & $-2.85(4.36)$ & $-8.25(4.46)$ & $-2.63(10.13)$ & $-3.63(5.28)$ & $-4.34(6.04)$ \\
\hline \multicolumn{6}{|l|}{ Day 1 , hour 12} \\
\hline Absolute (mmol/L) & $-0.11(0.09)$ & $-0.05(0.20)$ & $-0.05(0.22)$ & $-0.08(0.10)$ & $-0.07(0.14)$ \\
\hline Percentage & $-4.63(4.01)$ & $-1.73(7.80)$ & $-1.98(8.67)$ & $-3.37(4.32)$ & $-2.93(5.70)$ \\
\hline \multicolumn{6}{|l|}{ Day 2} \\
\hline Absolute (mmol/L) & $0.02(0.02)$ & $0.02(0.14)$ & $-0.02(0.25)$ & $0.15(0.09)$ & $0.05(0.14)$ \\
\hline Percentage & $1.12(1.14)$ & $1.22(5.51)$ & $-0.54(9.86)$ & $6.74(4.60)$ & $2.13(5.96)$ \\
\hline \multicolumn{6}{|l|}{ Day 3} \\
\hline Absolute (mmol/L) & $0.08(0.08)$ & $0.02(0.18)$ & $-0.05(0.19)$ & $0.09(0.10)$ & $0.04(0.14)$ \\
\hline Percentage & $3.72(3.45)$ & $1.29(7.10)$ & $-1.86(7.30)$ & $3.97(4.37)$ & $1.78(5.52)$ \\
\hline \multicolumn{6}{|l|}{ End of study } \\
\hline Absolute (mmol/L) & $0.05(0.10)$ & $0.02(0.32)$ & $0.01(0.18)$ & $0.14(0.13)$ & $0.05(0.18)$ \\
\hline Percentage & $2.26(4.27)$ & 1.19 (12.54) & $0.55(7.10)$ & $6.42(6.23)$ & $2.60(7.34)$ \\
\hline
\end{tabular}

However, a trend of greater exposure was observed in younger subjects as well as a trend of increasing exposure with decreasing BSA. Values for $\mathrm{AUC}_{0 \text {-inf }}, \mathrm{t}_{1 / 2 \beta}$, and $\mathrm{CL} / \mathrm{F}$ were not calculable in most subjects.

\section{Pharmacodynamics}

Consistent with the pharmacologic action of cinacalcet, mean (SD) percentage changes from baseline in serum $\mathrm{Ca}$ $(\mathrm{mmol} / \mathrm{L})$ concentration were observed from $2[-2.88$ $(5.40)]$ to $12 \mathrm{~h}[-2.93(5.70)]$ post-dose; returning to baseline levels by Day 2 (Fig. 4; Table 2). Mean (SD) percentage changes in serum iPTH $(\mathrm{pg} / \mathrm{mL})$ concentrations decreased -35.65 (55.82) from baseline values up to $2 \mathrm{~h}$ post-dose, increased to above baseline between 4 [24.10 (76.14)] and $12 \mathrm{~h}[57.94(71.82)]$ post-dose, and returned to baseline levels by Day 2 (Fig. 5; Table 3). The observed patterns of changes from baseline in mean serum $\mathrm{Ca}$ and $\mathrm{PTH}$ concentrations was similar for each age cohort (Figs. 4, 5); the small sample size per age-cohort precluded formal analysis.

\section{Discussion}

In this open-label study, we evaluated the safety, tolerability, pharmacokinetics, and pharmacodynamics of a single, oral 15-mg dose of cinacalcet in pediatric subjects 6-17 years of age with CKD who were on dialysis upon entry into the study. No serious adverse events developed as a result of hypocalcemia. All adverse events were mild to moderate in severity. The adverse events reported by the two subjects, bacteremia with pyrexia in one subject and a prolonged QTc

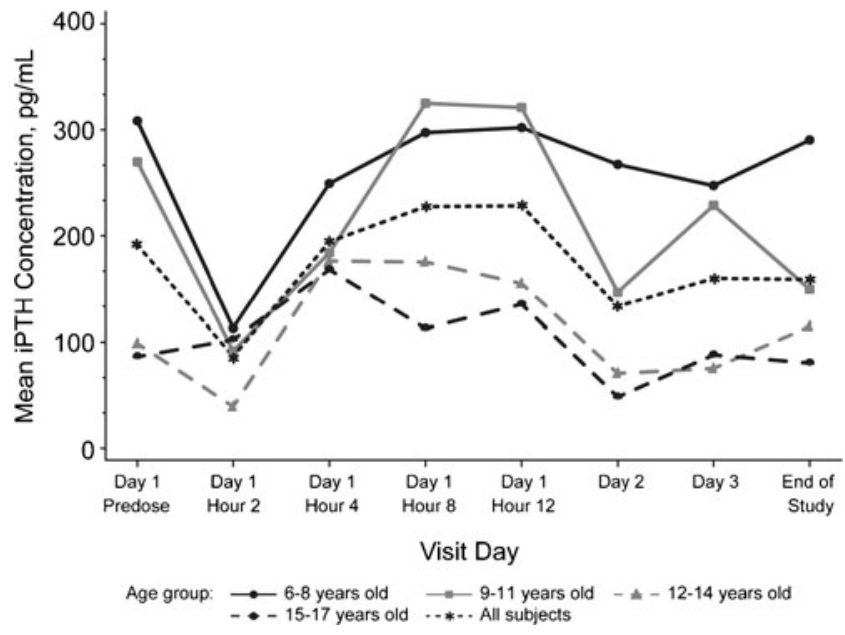

Fig. 5 Mean serum intact parathyroid hormone $(i P T H)$ concentrations by time for each age-cohort. Maximum mean \pm standard deviation decrease was $35.7 \pm 55.8 \%$ at $2 \mathrm{~h}$ post-dose; PTH returned to baseline level by Day 2 . The observed patterns of change from baseline were similar for each age-cohort 
Table 3 Mean changes from baseline over time in serum intact parathyroid hormone level for each age-cohort
Data are presented as the mean, with the standard deviation given in parenthesis

\begin{tabular}{|c|c|c|c|c|c|}
\hline \multirow[t]{2}{*}{ Time } & \multicolumn{4}{|l|}{ Age-cohort } & \multirow{2}{*}{$\begin{array}{l}\text { All subjects } \\
(n=12)\end{array}$} \\
\hline & $\begin{array}{l}6-8 \text { years } \\
(n=3)\end{array}$ & $\begin{array}{l}9-11 \text { years } \\
(n=3)\end{array}$ & $\begin{array}{l}12-14 \text { years } \\
(n=3)\end{array}$ & $\begin{array}{l}15-17 \text { years } \\
(n=3)\end{array}$ & \\
\hline \multicolumn{6}{|l|}{ Day 1 , hour 2} \\
\hline $\begin{array}{l}\text { Absolute } \\
\text { (pg/mL) }\end{array}$ & $\begin{array}{l}-195.33 \\
(159.07)\end{array}$ & $\begin{array}{l}-178.00 \\
(164.08)\end{array}$ & $-59.33(42.36)$ & $16.00(47.57)$ & $\begin{array}{l}-104.17 \\
(135.92)\end{array}$ \\
\hline Percentage & $-63.83(9.35)$ & $-14.03(99.53)$ & $-55.26(20.34)$ & $-9.49(56.84)$ & $-35.65(55.82)$ \\
\hline \multicolumn{6}{|l|}{ Day 1 , hour 4} \\
\hline $\begin{array}{l}\text { Absolute } \\
\text { (pg/mL) }\end{array}$ & $\begin{array}{l}-59.00 \\
(101.53)\end{array}$ & $-85.67(95.47)$ & 77.67 (87.64) & 81.67 (151.96) & $3.67(124.61)$ \\
\hline Percentage & 9.09 (66.66) & $-20.76(45.04)$ & $80.76(101.55)$ & $27.32(83.12)$ & $24.10(76.14)$ \\
\hline \multicolumn{6}{|l|}{ Day 1, hour 8} \\
\hline $\begin{array}{l}\text { Absolute } \\
\text { (pg/mL) }\end{array}$ & $-11.00(89.40)$ & $55.33(47.65)$ & $76.67(76.96)$ & $26.33(29.19)$ & $36.83(65.41)$ \\
\hline Percentage & $10.36(29.83)$ & $79.50(104.36)$ & $66.84(70.91)$ & $42.44(26.78)$ & $49.78(62.81)$ \\
\hline \multicolumn{6}{|c|}{ Day 1 , hour 12} \\
\hline $\begin{array}{l}\text { Absolute } \\
(\mathrm{pg} / \mathrm{mL})\end{array}$ & $-6.33(87.32)$ & $51.33(69.87)$ & $56.33(92.64)$ & $49.00(57.19)$ & $37.58(71.68)$ \\
\hline Percentage & $25.29(54.91)$ & $96.80(126.19)$ & $41.18(67.17)$ & $68.46(21.63)$ & $57.94(71.82)$ \\
\hline \multicolumn{6}{|l|}{ Day 2} \\
\hline $\begin{array}{l}\text { Absolute } \\
\text { (pg/mL) }\end{array}$ & $\begin{array}{l}-41.00 \\
(104.37)\end{array}$ & $\begin{array}{r}-123.00 \\
(180.59)\end{array}$ & $-28.00(4.58)$ & $-38.00(65.05)$ & $\begin{array}{l}-57.50 \\
(101.33)\end{array}$ \\
\hline Percentage & $-6.03(22.17)$ & $26.84(117.42)$ & $-31.55(13.24)$ & $-15.32(36.59)$ & $-6.52(58.03)$ \\
\hline \multicolumn{6}{|l|}{ Day 3} \\
\hline $\begin{array}{l}\text { Absolute } \\
\text { (pg/mL) }\end{array}$ & $\begin{array}{l}-61.00 \\
(114.01)\end{array}$ & $-41.00(47.79)$ & $-23.33(11.02)$ & $1.67(7.23)$ & $-30.92(58.22)$ \\
\hline Percentage & $-18.62(22.40)$ & $61.88(136.94)$ & $-23.38(4.68)$ & $-7.25(12.37)$ & $3.16(69.46)$ \\
\hline \multicolumn{6}{|l|}{ End of study } \\
\hline $\begin{array}{l}\text { Absolute } \\
(\mathrm{pg} / \mathrm{mL})\end{array}$ & $-18.00(68.35)$ & $\begin{array}{l}-120.00 \\
(139.57)\end{array}$ & $16.00(35.34)$ & $-6.00(15.87)$ & $-32.00(87.42)$ \\
\hline Percentage & $-7.45(17.58)$ & $\begin{array}{l}211.79 \\
(457.53)\end{array}$ & $16.38(41.31)$ & $9.58(26.94)$ & $57.58(217.46)$ \\
\hline
\end{tabular}

interval in the second subject, were considered by the investigators to be unrelated to treatment with cinacalcet. Overall, cinacalcet was well tolerated.

The mean pharmacokinetics exposure did not consistently increase with decreasing age; however, an overall trend of greater exposure in younger subjects was observed, which may be related to the lower body weight and BSA in younger subjects compared with older subjects. The mean $\mathrm{AUC}_{0-\mathrm{t}}$ and $\mathrm{C}_{\max }$ values following a single 15-mg dose of cinacalcet for the combined cohorts in this study were within approximately $30 \%$ of values observed following a single 30-mg dose (one 30-mg tablet) of cinacalcet administered to healthy adult subjects in a previous study (Amgen study 20060133; data on file).

The patterns of changes in serum $\mathrm{Ca}$ and $\mathrm{PTTH}$ concentration from baseline were similar between cohorts and within the expected ranges for patients with CKD. These findings are consistent with published data, which demonstrate a reduction in plasma iPTH levels as well as serum Ca and phosphorus levels for adult patients on hemodialysis following the administration of cinacalcet [5, 8, 19, 20]. Furthermore, results from small observational studies suggest that the administration of cinacalcet when PTH levels are between $300-500 \mathrm{pg} / \mathrm{mL}$ or $501-800 \mathrm{pg} / \mathrm{mL}$ decreases PTH to $<300 \mathrm{pg} / \mathrm{mL}$ within 16-28 weeks of therapy [11] (Amgen; data on file). Achieving therapeutic target ranges is important in decreasing the risk of other bone and mineral comorbidities associated with sHPT that when left untreated can lead to increased rates of hospitalization.

Although in combination with PTH level dialysis vintage may affect biochemical responses to cinacalcet, Padhi et al. previously reported that the use of dialysis (hemodialysis and peritoneal dialysis) does not affect the pharmacokinetics or pharmacodynamics of cinacalcet, as it is a lipophilic drug that is approximately $96 \%$ protein bound and not dialyzable [21]. Their study showed that baseline PTH levels increased with decreased renal function, while changes in Ca were not consistent from baseline to nadir and at peak concentrations. 
Therefore, the dose in the present study, based primarily on the BSA of subjects, was appropriately determined and did not need further modification based on dialysis.

These data are important since they provide the first formal pharmacokinetic and pharmacodynamic data related to the use of cinacalcet in children and support further investigation of cinacalcet to establish the appropriate starting dose for the treatment of SHPT in pediatric patients receiving dialysis. These data will now serve as the basis for determining drug dosing in prospective clinical trials designed to evaluate the safety and efficacy of cinacalcet in the pediatric dialysis population with SHPT.

\section{Limitations of current study}

This was a small, open-label study to evaluate the safety and describe the administration of a single-dose of cinacalcet in pediatric dialysis patients with sHPT. Due to the sample size no formal statistical comparisons were made in this study. Dialysis vintage was not collected; however, it was reportedly brief compared to adults since most pediatric patients are transplanted or return from transplant. Although the results from our study are consistent with observations in adults from the same population, the current analysis precludes drawing strong conclusions at this time. However, future studies of pediatric patients with a larger sample size will likely yield comparable results to the adult population.

Acknowledgments The authors would like to thank Holly Tomlin (employee and stockholder Amgen Inc.) for participation in the writing, editing, and journal formatting of the manuscript. Each author had full access to the data described and the manuscript drafts, and contributed to the final manuscript.

Open Access This article is distributed under the terms of the Creative Commons Attribution License which permits any use, distribution, and reproduction in any medium, provided the original author(s) and the source are credited.

\section{References}

1. Block GA (2000) Prevalence and clinical consequences of elevated $\mathrm{Ca} \times \mathrm{P}$ product in hemodialysis patients. Clin Nephrol 54:318-324

2. Goodman WG (2001) Recent developments in the management of secondary hyperparathyroidism. Kidney Int 59:1187-1201

3. Delmez JA, Tindira C, Grooms P, Dusso A, Windus DW, Slatopolsky E (1989) Parathyroid hormone suppression by intravenous 1,25dihydroxyvitamin D. A role for increased sensitivity to calcium. J Clin Invest 83:1349-1355

4. Wesseling-Perry K, Pereira RC, Sahney S, Gales B, Wang HJ, Elashoff R, Juppner H, Salusky IB (2011) Calcitriol and doxercalciferol are equivalent in controlling bone turnover, suppressing parathyroid hormone, and increasing fibroblast growth factor-23 in secondary hyperparathyroidism. Kidney Int 79:112-119

5. Block GA, Martin KJ, de Francisco AL, Turner SA, Avram MM, Suranyi MG, Hercz G, Cunningham J, Abu-Alfa AK, Messa P, Coyne DW, Locatelli F, Cohen RM, Evenepoel P, Moe SM,
Fournier A, Braun J, McCary LC, Zanie VJ, Olson KA, Drueke TB, Goodman WG (2004) Cinacalcet for secondary hyperparathyroidism in patients receiving hemodialysis. N Engl $\mathrm{J}$ Med $350: 1516-1525$

6. Drueke TB (2005) Treatment of secondary hyperparathyroidism of dialysis patients with calcimimetics as a valuable addition to established therapeutic means. Pediatr Nephrol 20:399-403

7. Lindberg JS, Culleton B, Wong G, Borah MF, Clark RV, Shapiro WB, Roger SD, Husserl FE, Klassen PS, Guo MD, Albizem MB, Coburn JW (2005) Cinacalcet $\mathrm{HCl}$, an oral calcimimetic agent for the treatment of secondary hyperparathyroidism in hemodialysis and peritoneal dialysis: a randomized, double-blind, multicenter study. J Am Soc Nephrol 16:800-807

8. Moe SM, Cunningham J, Bommer J, Adler S, Rosansky SJ, UrenaTorres P, Albizem MB, Guo MD, Zani BJ, Goodman WG, Sprague SM (2005) Long-term treatment of secondary hyperparathyroidism with the calcimimetic cinacalcet $\mathrm{HCl}$. Nephrol Dial Transplant 20:2186-2193

9. Nemeth EF, Steffey ME, Hammerland LG, Hung BC, Van Wagenen BC, DelMar EG, Balandrin MF (1998) Calcimimetics with potent and selective activity on the parathyroid calcium receptor. Proc Natl Acad Sci USA 95:4040-4045

10. Brown EM, Gamba G, Riccardi D, Lombardi M, Butters R, Kifor O, Sun A, Hediger MA, Lytton J, Hebert SC (1993) Cloning and characterization of an extracellular $\mathrm{Ca}(2+)$-sensing receptor from bovine parathyroid. Nature 366:575-580

11. Block GA, Zeig S, Sugihara J, Chertow GM, Chi EM, Turner SA, Bushinsky DA (2008) Combined therapy with cinacalcet and low doses of vitamin D sterols in patients with moderate to severe secondary hyperparathyroidism. Nephrol Dial Transplant 23:2311-2318

12. Goodman WG, Hladik GA, Turner SA, Blaisdell PW, Goodkin DA, Liu W, Barri YM, Cohen RM, Coburn JW (2002) The Calcimimetic agent AMG 073 lowers plasma parathyroid hormone levels in hemodialysis patients with secondary hyperparathyroidism. J Am Soc Nephrol 13:1017-1024

13. Moe SM, Chertow GM, Coburn JW, Quarles LD, Goodman WG, Block GA, Drueke TB, Cunningham J, Sherrad DJ, McCary LC, Olson KA, Turner SA, Martin KJ (2005) Achieving NKF-K/DOQI bone metabolism and disease treatment goals with cinacalcet $\mathrm{HCl}$. Kidney Int 67:760-771

14. Goodman WG (2003) Calcimimetic agents and secondary hyperparathyroidism: rationale for use and results from clinical trials. Pediatr Nephrol 18:1206-1210

15. Silverstein DM, Kher KK, Moudgil A, Khurana M, Wilcox J, Moylan K (2008) Cinacalcet is efficacious in pediatric dialysis patients. Pediatr Nephrol 23:1817-1822

16. Muscheites J, Wigger M, Drueckler E, Fischer DC, Kundt G, Haffner D (2008) Cinacalcet for secondary hyperparathyroidism in children with end-stage renal disease. Pediatr Nephrol 23:1823-1829

17. Strippoli GF, Tong A, Palmer SC, Elder G, Craig JC (2006) Calcimimetics for secondary hyperparathyroidism in chronic kidney disease patients. Cochrane Database Syst Rev:CD006254

18. Padhi D, Harris R (2009) Clinical pharmacokinetic and pharmacodynamic profile of cinacalcet hydrochloride. Clin Pharmacokinet 48:303-311

19. Chertow GM, Blumenthal S, Turner S, Roppolo M, Stern L, Chi EM, Reed J (2006) Cinacalcet hydrochloride (Sensipar) in hemodialysis patients on active vitamin D derivatives with controlled PTH and elevated calcium x phosphate. Clin J Am Soc Nephrol 1:305-312

20. Meola M, Petrucci I, Barsotti G (2009) Long-term treatment with cinacalcet and conventional therapy reduces parathyroid hyperplasia in severe secondary hyperparathyroidism. Nephrol Dial Transplant 24:982-989

21. Padhi D, Harris RZ, Salfi M, Sullivan JT (2005) No effect of renal function or dialysis on pharmacokinetics of cinacalcet (Sensipar/ Mimpara). Clin Pharmacokinet 44:509-516 